\begin{tabular}{|ccc|}
\hline & ANNALES INSTITUTI SLAVICI \\
& UnIVERSITATIS DEBRECENIENSIS & \\
SLAVICA XLVII & 2018 & DEBRECEN \\
\hline
\end{tabular}

\author{
Agnieszka JANIEC-NYITRAI
}

\title{
„REAGOWAĆ Z SZYBKOŚCIA KOBRY NA CODZIENNOŚĆ” \\ O PUŁAPKACH AKTUALNOŚCI - KRONIKI BESKIDZKIE I ŚWIATOWE (2018) \\ ANDRZEJA STASIUKA
}

\author{
"React with Cobra's Speed to Everyday Life" \\ On the Trap of Actuality - Andrzej Stasiuk's Beskidy and World Chronicles \\ (2018)
}

The goal of the paper is to analyze and depict the essays written by Polish contemporary author Andrzej Stasiuk in the wider context of writing strategies. The essays were collected in Beskidy and World Chronicles (2018). The paper also deals with Stasiuk's "workshop comments" about the art of writing and is concerned with author's attitude to changes in social, cultural and political life. Stasiuk searches for harmony and calmness. What he writes about is not topicalities but universal themes: nature, philosophy of living, everyday life. All that he can see in mass media is very strange and outlandish for him, while he looks for eternal values, describing chaos in modern world.

Keywords: Art of writing, writing strategies, Andrzej Stasiuk, contemporary Polish literature

\section{Wstęp}

Felietony Andrzeja Stasiuka, zebrane w tomie Kroniki beskidzkie $i$ światowe (2018), były publikowane w „Tygodniku Powszechnym” w latach 2013-2018, w rubryce pod tym samym tytułem. Stasiuk należy do najwybitniejszych polskich pisarzy współczesnych, a jego powieści, opowiadania i eseje podróżnicze są thumaczone na wiele języków. Stasiuk nie stroni od krótszych form wypowiedzi artystycznej, ważne miejsce w jego twórczości zajmują relacje z podróży, szczególnie po Europie Środkowej, Bałkanach, a ostatnio Rosji. Felieton jako hybrydyczny gatunek dziennikarski wydaje się więc być interesującym wyborem dla pisarza, który wciąż poszukuje „nowych wyzwań” i dla którego punktem wyjścia jego literackich poszukiwań jest rzeczywistość.

„Nie ma wątpliwości co do takich cech felietonu, jak: usytuowanie na pograniczu publicystyki i literatury, aktualność poruszanej problematyki, pasożytnictwo tematyczne i gatunkowo-stylistyczne, tematyczna dowolność, subiektywność, a nawet stronniczość wypowiedzi, pełna swoboda stylistyczna, skłonność publicystów do silnego wartościowania w sposób prześmiewczy". [BARAŃSKA-SZMITKO 2014: 214]

Jednakże posługując się tak popularnym gatunkiem dziennikarskim, Stasiuk potrafi odnaleźć swój własny, niepowtarzalny styl. Często pojawiającym się motywem felietonów autora Opowieści galicyjskich jest refleksja nad wyborem tematu tekstu. 
Teksty felietonistyczne pisarza zawierają rozważania na temat samego pisania i poszukiwania inspiracji, co z kolei prowadzi do głębszegonamysłu nad współczesnością. Rozważania te są dla Stasiuka pretekstem do wystawienia gorzkiego świadectwa dzisiejszej rzeczywistości, mówią o błahości, jednorazowości otaczającej wrażliwą jednostkę, o docierającym zewsząd i nie dającym się stłumić szumie informacyjnym, o powierzchownym podglądzie rzeczywistości, pojawiającym się w mediach, o nieistotności większości poruszanych tematów. Stasiuk jest nieufny wobec zmian zachodzących we współczesnym świecie, z uwagą śledzi pogoń mediów za aktualnościami, rozważa również kwestie zmieniających się sposobów międzyludzkiej komunikacji. Tym samym autor wykorzystuje felieton do poruszania kwestii uniwersalnych, ale jednocześnie jego artykuły zawierają wyraźny metatekstualny podtekst, w którym Stasiuk pisze o tym, w jaki sposób tworzy, czym się charakteryzują jego teksty, jak powstają, są to więc felietony w dużym stopniu autotematyczne (w nieco szerszym pojęciu niż to zaproponowane przez Artura Sandauera), autoteliczne, traktujące o samym procesie pisania.

Celem artykułu będzie analiza zawartych w felietonach „uwag warsztatowych” Stasiuka, dotyczących pisania i doboru tematów ujęta w szerszej perspektywie zmian dotykających współczesnego świata. Chciałabym również zasygnalizować, jak Stasiuk radzi sobie z wszechogarniającą kakofonią informacyjną, jak poszukuje harmonii między tym, co błahe, a tym, co relewantne, do jakich strategii się ucieka, aby jego felietony nie stały się częściąnatłoku informacyjnego.

Stasiuk w felietonach poświęconych pisaniu dzieli się z czytelnikami swoim pisarsko-dziennikarskim credo, odsłania arkana swej ars poetica, nie ukrywa swojego krytycznego stosunku do rzeczywistości i wątpliwości, nurtujących go w związku z przemianami świata, które zachodzą na jego oczach.Pokazuje, w jaki sposób radzi sobie lub też nieradzi z ciśnieniem aktualności, która staje się wymogiem przy pisaniu tekstów felietonistycznych [BARAŃSKA-SZMITKO 2014: 215]. Skoncentruję się na sześciu wybranych felietonach, w których autor w sposób najpełniejszy porusza interesujące mnie kwestie. Warto zaznaczyć, że autoteliczność „felietonu o felietonie" (nawiązuję tu do znanego tekstu Cypriana Kamila Norwida z 1851 r.) jest dla Stasiuka jedynie pretekstem do bardziej szczegółowych rozważań o istocie świata i stanowi jedynie pewien aspekt wielowymiarowych i znaczeniowo niezwykle bogatych tekstów ze zbioru Kroniki beskidzkie i światowe. Horyzont moich analiz będą więcwyznaczać, z jednej strony uwagi nad genologiczną przynależnością felietonu jako gatunku dziennikarskiego sytuującego się na przecięciu literatury $i$ publicystyki, a z drugiejrozważania nad filozoficznymi aspektami aktualności i jej roli w wyborze tematyki wypowiedzi literackiej. 


\section{Fakciki i figurynki}

Felieton „Przedłużając” rozpoczyna się od ważnych słów, wprowadzających czytelnika w samo sedno problemu:

„Ustaliliśmy z Redaktorem, że trochę za poważnie mi ostatnio idzie. W felietonach znaczy. Że jakaś niewyraźna mistyka, że sprawy fundamentalne, a chwilami nawet obskurantyzm. Tak ustaliliśmy wspólnie i się z tym zgodziłem. Bo rzeczywiście gatunek felietonu nie może padać ofiarą pokątnej metafizyki i amatorskiej eschatologii. Nie może, gdyż musi raźno oraz inteligentnie reagować na bieżącą rzeczywistość, a o sprawach ostatecznych jest czas pomyśleć na przykład w szpitalu." [STASIUK 2018: 68].

W przytoczonym fragmencie pojawia się wyraźny ton ironiczny. „Bieżąca rzeczywistość" wymaga reagowania na nią, co jest jednak niemożliwe, biorąc pod uwagę tempo zmian, jakie owej rzeczywistości przypadają w udziale.Zmiany, dotykające świata, są jednak tylko chwilowe, doraźne, nie są fundamentalne, anatłok wydarzeń wyklucza możliwość rzetelnego zastanowienia się nad tym, co się właściwie dzieje. Każda zmiana, każde zdarzenie, każda sytuacja niejako wymuszają na pisarzu reakcję. Stasiuk zwierza się z własnej niemocy, z niemożności ogarnięcia ciągłej fluktuacji świata, który, niczym znudzone dzieci, w sposób krzykliwy i nie znoszący sprzeciwu domaga się jego uwagi.

„No dzieje się i dzieje, ale zaraz jakby przestawało. Dzieje się jedno za długim. Człowiek by nawet chciał, ale zanim coś zanotuje, to już jest następne. Już, już coś ma, już ma odpalić Worda, a to coś znikło i zrobiło miejsce kolejnemu. Popatrzeć dalej, a tam następne stoją w długaśnej kolejce. Pchają się, nadeptują na siebie, popychają, przepychają, kuksańce kolejkowym sąsiadom wymierzają, tłoczą się jak w ogonku z dawnych czasów. Wydarzenia biedne. Fakty niebożęta. Żeby się tylko przepchnąć oczko dalej i żebyśmy spojrzeniem tknęli je choć na moment." [STASIUK 2018: 68-69].

Stasiukowi mocno doskwiera natłok informacji i idąca za tym niemożność uchwycenia świata, jego przemijalność. Przeszkadza mu linearny pęd wydarzeń i szum informacyjny, stąd rodzi się ważkie pytanie: jak wyodrębniać, według jakiego klucza przyklejać etykietkę ważne/nieistotne? Zdarzania są efemeryczne, błahe, ulotne, aw zgiełku, w pośpiechu umykają szczegóły, a właśnie Stasiuk zaliczany jest do pisarzy wyjątkowo wyczulonych na detale [FRANKOWIAK 2011: 71].

„No ale cóż ja - biedny felietonista wiejski bez złamanego programu, bez nawyku kupowania gazet, a szczerze mówiąc, i bez zainteresowania specjalnego - cóż ja mogę wobec tej apokaliptycznej nawały rzeczywistości? Jak odróżnić ważne od mniej ważnego? Ziarno od plew odsiać? Jak zdecydować, co przetrwa, a co przepadnie, i czemu poświęcić moje cztery tysiące znaków? [...) Nie wiem, Redaktorze. w którąkolwiek stronę się obrócisz, tam czyha temat albo się wyłania postać. Jak oddać sprawiedliwość światu i niczego nie pominąć? Pisać bez przerwy, bez snu, bez jedzenia, produkować teksty non stop jak jakiś obłąkany felietonistyczny telewizor?" [STASIUK 2018: 69-70]. 
Wspomniany już Artur Sandauer, twórca pojęcia „,autotematyzm”, ujmuje następująco przebieg „mąk twórczych”, które owocują, podobnie jak u Stasiuka, powstaniem felietonu:

„Niemożliwość wykonania, daremne wysiłki i przerażenie wobec niepowstałego dzieła będą przedmiotem tego, które powstaje, skupione całe dokoła nieistniejącego środka, zorganizowane wokół ssącej próżni centralnej." [SANDAUER 1971: 44].

Stasiuk jest przytłoczony nadmiarem tematów i impulsów, które blokują jego zdolność pisania, staje bezbronny wobec nawału informacji. Stara się jednak nie ulegać żadnej z dwu typowych reakcji na szum informacyjny, o których piszą Tomasz Goban-Klas i Piotr Sienkiewicz:

„Pierwsza to gorączkowe przerzucanie się od przekazu do przekazu (co odpowiada przerzucaniu książek w bibliotece, naciskaniu pilota telewizora, ciągłe poszukiwanie nowych programów komputerowych), druga zaś to uporczywe trwanie przy swych dotychczasowychprzyzwyczajeniach (pozostawanie przy jednym kanale radiowym, telewizyjnym, kupno tej samej gazety i tygodnika)." [GoBAN-KLAS-SIENKIEWICZ 1999: 113].

Stasiuk pyta retorycznie Redaktora, jak wyjść z tego impasu, jak nie dać się ponieść frustracji, wynikającej z niemożności uchwycenia świata w jego pozornej, płytkiej, teraźniejszej jedynie złożoności? Samego autora tekstu Stasiuk portretuje jako wybawiciela, który z błyskiem szaleństwa w oku przezwycięża swoją obojętność i ratuje odchodzącą w niebyt, starzejącą się aktualność.

„Mamyż nie ustawać i do siódmych potów, do grobowej deski przedłużać życie faktom i fakcikom, postaciom i figurynkom na tej opętanej scenie życia, na którą się rwie siedem miliardów chętnych do występu?" [STASIUK 2018: 70].

Świat staje się rozproszoną na tysiące fragmentów fatamorganą, a człowiekowi wydaje się, że uda mu się posklejaćową umykającą, przeciekającą przez palce rzeczywistość poprzez złożenie jej z tysiąca cząstek, co jest fizycznie niemożliwe. Stąd poczucie frustracji -wszechogarniające uczucie, że wciąż coś umyka, znika niepoznane i nieopisane. Ale człowiek nie musi przecież mozolnie składać świata z nieistotnych przejawów jego istnienia, może pozwolić „wyszumieć” się światu w feerii faktów i fakcików, figur i figurynek, ale jednocześnie nie uronić nic ze złożoności świata, nie zwracając uwagi na jego błahe emanacje.

Motywacją pogoni za aktualnością jest strach przed przemijaniem, niepogodzenie się z upływem czasu. Opisywanie świata poprzez kurczowe trzymanie się aktualności jawi się jako przedłużanie życia, jako reanimacja teraźniejszości, która już w momencie swojego zaistnienia staje się przeszłością i wpada w przepaść zapomnienia.

„No dobrze - trochę się usprawiedliwiam, że nie chce mi się reagować z szybkością kobry na codzienność. Obiecuję, że się poprawię i chwycę za gardło teraźniejszość, tym samym nieco ja reanimując i przedłużając jej życie”. [STASIUK 2018: 71]. 
Podobne rozważania zawarł Stasiuk w felietonie „Zanim się zacznie”.

„I weź tu, człowieku, pisz felieton. Reaguj na bieżące, naród i ojczyznę za puls trzymaj. Rób sobie transfuzję z aktualności. (...) Szczerze mówiąc mnie to przerasta. Jak wiele rzeczy, na które jako felietonista powinienem reagować". [STASIUK 2018: 194]

Owo „trzymanie za puls” oznacza ciągłą gotowość na reakcję, ciągłe natężanie uwagi, by wychwycić wszystkie przejawy rzeczywistości. Potrzeba ciągłego reagowania na najmniejsze nawet drgnienia świata, na bieżące bolączki, na najmniejsze nawet zmiany jest na dłuższą metę nie do zniesienia, czyni człowieka zakładnikiem świata, w którym przyszło mu żyć, nakłada na jego barki nieznośny ciężar odpowiedzialności - wszystko trzeba opisać, nic nie może umknąć uwadze, bo inaczej obraz będzie fragmentaryczny, niepełny.

Nadmiar bodźców powoduje wyraźny dyskomfort i rozdrażnienie. Tak jest w felietonie „Czwarta trzydzieści”:

„Znowu zbliża się termin. Pojutrze mam wysłać felieton. Nerwowo rozmyślam nad tematem. Wszędzie tematy. Gdziekolwiek się obejrzysz. Tematów jak psów.” [STASIUK 2018: 118].

Tematyczny zgiełk i galimatias nie sprzyjają filozoficznym rozważaniom, rozpraszają, a w rezultacie czynią człowieka nieczułym i niewrażliwym na świat. Cała energia poświęcana jest na odnalezienie jednego, wymarzonego tematu, ale towarzyszy temu przykre uczucie, że świat w międzyczasie umyka, przecieka przez palce. To poczucie frustracji wynikające $z$ niemożności zapanowania nad światem niszczy człowieka, odbiera mu radość pisania.

Dlatego Stasiuk nie zgadza się na to, aby felieton stawał się jedynie reakcją na otaczający świat, na impulsy buzujące ze wszystkich stron. Jego filozofia felietonu pozostaje więc w opozycji do pojmowania tego typu tekstu jako gatunku pasożytniczego, które pojawiło się już w pismach Cypriana Kamila Norwida w połowie XIX wieku [STASIŃSKI 1982: 9]. Norwid pisze:

„To, czym w dziedzinie naturalnego piękna jest na przykład familia tak zwanych roślin pasożytnych, oplatających głaz i drzewo, często niszczących je powolnie, a dających wzór do arabeski, która w architekturze (tym pięknem już nadnaturalnym) świat ów zastępuje... to jest w politycznej sferze postaci: felieton.” [NORWID 1968: 185].

Według Stasiuka felieton nie powinien pasożytniczo czerpać z innych gatunków, nie powinien być też niewyszukanym komentarzem do rzeczywistości, nie powinien żywić się aktualnościami, które podatne są na upływ czasu i stają się bardzo szybko nieaktualne, przestarzałe.

Pojmowanie tego gatunku dziennikarskiego przez Stasiuka różni się od definicji Andrzeja Niczyperowicza, który, idąc za tokiem rozumowania zasygnalizowanym przez Norwida, uznaje felieton za „pięknego pasożyta”: „Autor przy biurku przeżuwa wyczytane informacje, obejrzane w telewizji obrazki i wysłuchane na falach radiowych pogwarki. I z tego kleci tekst na miarę swojego talentu" [NICZYPEROWICZ 1996: 46].Stasiuk odmawia „przeżuwania”, „klecenia”, wsłuchiwania się w „radiowe pogwarki", dla niego felieton jest gatunkiem szlachetnym, gatunkiem, który 
powinien być oryginalny, nieść nowe przesłania i nie pasożytować na wątpliwej jakości aktualnościach.

\section{Czlowiek bezbronny wobec lawiny słów}

W tekście noszącym znamienny tytuł „Gadu-gadu” Stasiuk porusza kwestie deformacji, którym podlega współcześnie międzyludzka komunikacja. Człowiek znajduje się w pułapce słów, jest osaczany przez nieustannie płynący strumień opinii, komentarzy, uwag, przed którymi nie można się ukryć.

„Tak więc nie ma ucieczki. Musisz słuchać, co ci mają do powiedzenia. W autobusie, w pociągu, w tramwaju, w metrze. A jak na chwilę zamilkną, to puszczają obrazki. Gdziekolwiek się zwrócisz - gadanina. Jedni przekonują drugich. Wzdęci od swojej prawdy, z wąsami, bez wąsów, kobiety, mężczyźni, zwierzęta z podłożonymi ludzkimi głosami, sprzęt AGD do ciebie mówi, wdzięczy się proszek do prania, politycy mówią swoje, bez żadnych znaków przestankowych, ewentualnie $\mathrm{z}$ krótkimi przerwami na oddech. Bez szans na ciszę, bez chwili na własną myśl, chyba że umrzesz." [STASIUK 2018: 106-107].

Mass media serwują nie kończący się słowotok, ciąg słów wykastrowanych ze znaczeń, będących jedynie pustą formą wyzutą z treści. Dogłębną analizę tego zjawiska znaleźć można w felietonie „De profundis”, w którym zawarte są przemyślenia Stasiuka,rodzące się pod wpływem słuchania radia. Programy radiowe prowadzą ,herosi obłej gadki, fajterzy słowotoku" [STASIUK 2018: 91-92], a w ich ustach słowa, zdania, komentarze stają się kompletnie błahe, puste.Sieczka radiowa służy tylko i wyłącznie do zapełnieniu ciszy, która jest niebezpieczna, ponieważ stwarza przestrzeń do myślenia.Zagłuszanie ciszy jest praktykowane w każdym medium, ponieważ cisza jest groźna, szkodliwa i zagrażająca. Samo mówienie, namnażanie nic nie znaczących słów jest porywające, hipnotyczne, ale puste, ponieważ, jak już wspomniałam wcześniej, słowa te nie niosą żadnego przekazu, są jedynie znakami pozbawionymi sensu.

„A pomiędzy - klajster, żeby się nie rozlazło. Muzykę, znaczy się, puszczają szamani fal ultrakrótkich. Nawet już nie mówią, jak kiedyś, co puszczają, bo to leci w kółko, bez końca, bez początku, ciągnie się jak edamski na zapiekance, jak guma do żucia, co jest nie do zjedzenia i nie do wyplucia.” [STASIUK 2018: 92].

Stasiuk włącza radio Maryja, żeby „usłyszeć ludzki głos, odnaleźć opowieśćc [STASIUK 2018: 92], ale i tam doścignąć go może „gładka ględźba” [STASIUK 2018: 92], prowadzących.Tylko czasem da się usłyszeć prawdziwe głosy słuchaczy, niećwiczone, realne, rzeczywiste, głosy z głębokości (de profundis), przybywające jakby z otchłani, z innego świata.

\section{Kultura vs. natura}

Stasiuk często przeciwstawia w swoich felietonach świat kultury uniwersalnemu światu natury. Tak jest w tekście zatytułowanym „Śniła mi się kultura”.Kultura to nadmiar bodźców, impulsów, które atakują wrażliwego człowieka. Sen o kulturze, a raczej koszmar o kulturze przedstawia natłok filmów do obejrzenia, natłok książek do przeczytania, natłok piosenek do wysłuchania, tekstów do zrecenzowania... Człowiek staje bezbronny wobec potoku dzieł ludzkich rąk i umysłów, i znów musi 
sobie zadać kardynalne pytanie: jak wyłuskać to, co wartościowe? [STASIUK 2018: 102-103].Kontrast do tego nawarstwienia znaczeń, narracji, myśli i opinii tworzy natura: owce, góry, drzewa, spokój, harmonia, psy i cisza, które nie wymagają od człowieka natychmiastowej reakcji, które nie są agresywne i istnieją również wtedy, jeśli człowiek na nie od razu nie zareaguje. Wymogiem istnienia natury nie jest szybka reakcja człowieka na nią, natura istnieje równolegle do człowieka, jest osobna.Inaczej jest w przypadku kultury, bo nieczytane książki, nieobejrzane przedstawienia, niewysłuchane piosenki odchodzą w niebyt, posiłkują szeregi dzieł odrzuconych, na które świat pozostał obojętny.

Swoją ucieczkę od nadprodukcji w kojące ramiona natury Stasiuk opisuje również w felietonie „Czwarta trzydzieści” [STASIUK 2018: 121]. Zamiast opędzać się od natrętnych tematów, należy spojrzeć przez okno na wielki świat, na monumentalność przyrody, bo ta nie przemija. Stasiuk ujmuje przyrodę w kategoriach mitycznych, archaicznych, dla których aktualność jest nic nieznaczącą kategorią.

Stasiuk niezwykle chętnie opisuje świat, w którym na pierwszy rzut oka nie dzieje się nic [COBEL-TOKARSKA-DĘBICKI 2018: 153]. Ta fascynacja bezzdarzeniowością wynika właśnie z buntu przed natarczywą aktualnością. To, że pozornie nic się nie dzieje, pozwala zatrzymać się, wyhamować, dostrzec to, co nie jest możliwe do zobaczenia w ruchu. Stasiuk z nostalgią opisuje przeszłość, która charakteryzowała się właśnie owymzbawiennym i wyciszającym „nic nie dzianiem się”:

„Nie działo się prawie nic. A jak się już wydarzyło, to automatycznie nabierało znaczenia. Trzeba było nieustannie myśleć i uruchamiać wyobraźnię, żeby wypełnić ciszę i pustkę. Dzisiaj musimy się opędzać, oganiać od tego wszystkiego, co kłębi się wokół i chwyta za nogawki." [STASIUK 2018: 71]

\section{Jak uciec z impasu?}

Stasiuk zanurzony w kakofonii dźwięków, zmuszany do ustawicznego kontaktu z agresywnym światem, atakującym go informacjami, stara się znaleźć swoją niszę. Są to dla niego tematy uniwersalne, związane z przyrodą, sensem ludzkiego życia, poetyckie rozważania o codzienności. Dla autora niezwykle istotny jest dystans, który pozwala dostrzec to, co ważne pod powierzchnią banalnych wydarzeń. Nota bene właśnie dystans, pewne ironiczne i autoironiczne ujęcie tematu stanowią ważny element felietonu jako gatunku dziennikarskiego [CHUDZIŃSKI 2008: 356]. Stasiuk nieustannie podpatruje świat, ale nie koncentruje się na tym, co chce być za wszelką cenę zauważone, raczej stara się wyłowić powiązania, odnaleźć ukryte analogie. Dopiero $\mathrm{z}$ perspektywy czasu pewne zdarzenia i sytuacje zaczynają istnieć $\mathrm{w}$ innym świetle, to właśnie upływający czas nadaje im sens. Nieprzemijająca wartość może być dostrzeżona dopiero przez ludzi kontemplujących sens zdarzeń z pewnym namysłem, a nie goniących za sensacją.

Antidotum na pęd świata stają się cisza i pustka, wsłuchanie się w siebie, swoisty post duchowy od zmieniającej się jak w kalejdoskopie codzienności prezentowanej przez media. W swojej twórczości, szczególnie w esejach podróżniczych z tomu Wschód (2014), Stasiuk, jak zauważa Marek Bernacki, ucieka się do obrazów pustki, nicości, w której ludzki subiekt rozpływa się, rozpuszcza [BERNACKI 2014: 86]. 
Jedną z cnót staje się pewna wybiórczość percepcji, brak zachłanności w metafizycznej i filozoficznej konsumpcji świata. Człowiek, wsłuchując się w siebie. znajduje odskocznię od płytkiej aktualności. Felietony Stasiuka to jednocześnie pochwała ciszy, skrótu myślowego, pochwała nienarzucania się ze swoimi opiniami, to pochwała filozoficznej refleksji, która rodzi się z milczenia, z uważnej obserwacji świata. U Stasiuka, jak zauważa Bożena Witosz, analizując wcześniejsze teksty prozatorskie pisarza, ważne miejsce zajmuje poszukiwanie bliskości, bliski, niemal zmysłowy kontakt z opisywanym i kreowanym światem, który dokonuje się nie poprzez zmysł wzroku, ale całościowe ogarnięcie rzeczywistości przy pomocy języka wypowiedzi [WITOSZ 2002: 139-140]. Tym samym dla Stasiuka nieznośne są kalejdoskopowe, chaotyczne zmiany, pogoń za aktualnością, ponieważ w tak rozproszonej perspektywie osiągnięcie bliskości nie jest możliwe, niweluje także dystans, który jest paradoksalnie jednym z warunków osiągnięcia bliskości.

Wiesław Setlak snując rozważania o filozofii mobilności Stasiuka zauważa, iż pisarzowi blisko do nomady: „Stan taki wyróżnia się tym, że podmiot nie dąży ani do kontroli natury przez kulturę, ani też do kontroli kultury przez naturę, a tym bardziej do hegemonii którejś z tych sfer." [SETLAK 2015: 45].Potrzebne jest mu poczucie bycia odrębnym, obcym, przybyszem. Stasiuk stara się patrzeć na świat „obcymi oczami”, nie pozwala wciągnąc się w grę z rzeczywistością, która ograniczać się może do pogoni za płytkimi aktualnościami. Pogoń ta na dłuższą metę jest bezowocna, bo nie da się uchwycić całego świata we wszystkich jego przejawach, a co więcej, teksty, które powstają podczas „fatalnego zauroczenia” aktualnościami, są tekstami jednorazowego użytku - bardzo szybko przestają być aktualne, starzeją się, stają się nieczytelne bez znajomości kontekstu.

Stasiuk znajduje się w potrzasku wymuszonej aktualności, zdaje sobie sprawę z tego, że nie może nadążyć za zmieniającym się światem i wie, że nie chce brać udziału w tym bezmyślnym wyścigu. Dlatego ucieka się do tematów odwiecznych, kwestii uniwersalnych, zawsze starając się z codzienności wyłuskać element pierwotny, niezmienny, szukając matrycy, powtarzalności, systemu w tym natłoku impulsów. Tematyczna struktura jego felietonów jest złożona - opiera się na faktycznej obserwacji rzeczywistości, ale rzeczywistość ta przefiltrowana jest przez „okulary wiecznego". Stasiuk nie ucieka w „pokątną metafizykę i amatorską eschatologię" [STASIUK 2018: 68], jest świadomy swoich ograniczeń, skromny w swoich spostrzeżeniach, nienarzucający swojej wizji świata, nieprzekonujący na siłęi nieprzekonany o swojej jedynej prawdzie. Jego artykuły, pomimo iż nie śledzą aktualności pojmowanych w kategoriach dziennikarskich jako komentarz do aktualnych wydarzeń i zjawisk, są głęboko zakorzenione, osadzone w rzeczywistości. W tym właśnie tkwi paradoks jego tekstów. Stasiuk przypomina raczej filozofa aktualności, który, podobnie jak wcześniej Nietzsche, a później Foucault, odrzuca fascynację wyabstrahowanymi przypadkami, zawieszonymi w niebycie i abstrakcji, niepowiązanymi w żaden sposób z tu i teraz, i zwraca się ku realnie istniejącemu światu. 
„Filozofia jako diagnostyka aktualności jest zbyt wyczulona na kwestię uczasowienia myśli, właściwego jej bycia-w-czasie (...), by uważać się za jakiś całkowicie niezaangażowany, zewnętrzny wobec swego przedmiotu opis. Diagnozowanie oznacza zajmowanie pozycji, a w każdym razie pewnego rodzaju sytuowanie się w tym lub wobec tego, co aktualne".[HERER 2012: 301].

W tym aspekcie dostrzec można paralele ze sposobemwidzenia świata u wspomnianego już Cypriana Kamila Norwida, który w tekście „O felietonie felieton” podkreśla względność i subiektywność prawd, typową dla tego gatunku:

„Felieton, tak jak każde na polu sztuki postaciowe zjawisko, względną ma swoją prawdę. Poszukiwać w nim prawdy obowiązującej bezpośrednio i prawdy ściśle literalnej byłoby to poszukiwać nie prawdy w formie felietonu (...) Prawdy obowiązujące bezpośrednio wychodzą za obręb felietonu, stanowią główną część dziennika. Felieton jest liryzmem politycznym". [NORWID 1968: 185].

Jeśli dokładniej przyjrzymy się definicji felietonu, stwierdzimy, iż Stasiuk dalece wykracza w kwestiach doboru tematyki poza klasycznie rozumiane ramy tego gatunku:

„Felieton jest stałą pozycją w dziennikach, tygodnikach, miesięcznikach, także w mediach elektronicznych. Zajmuje się najczęściej aktualnymi w danym momencie wydarzeniami kulturalnymi, społecznymi, gospodarczymi. Powinien być pisany dla rozrywki czytelników, w tonie swobodnym o dużym zabarwieniu satyrycznym, nawet skandalizującym. Swoboda językowa felietonu wiąże się z wolnością tematyczną. Autor felietonu ma prawo manifestować swój subiektywny punkt widzenia, podkreślać uczuciowość i zaangażowanie w dane sprawy. Wypowiedź jego cechuje familiarność i podkreślanie wolności intelektualnej. Stylistycznie felieton korzysta z mowy potocznej (w tym kolokwializmów, nawet wulgaryzmów), ale i ze środków typowo literackich, a także prawa do kreowania fikcji" [WOLNY-ZMORZYŃSKI et al. 2006: 88].

Stasiuk pośpiech zastępuje namysłem, nie ma poczucia, że coś mu ucieka, że trwoni czas, ponieważ czas w jego pojęciu nie pędzi do przodu, nie ma formy linearnej, ale raczej cykliczną, nawiązującą do pierwotnego rozumienia czasu. Wiedza o aktualnościach jest człowiekowi całkowicie zbędna, a największym wrogiem twórcy jest doraźność, tymczasowość, nietrwałość i dorywczość. Aktualność nie oznacza w rozumieniu Stasiuka otwarcie się na problemy współczesności, ale raczej zanurzenie się w miałkich otchłaniach doraźności. Jednocześnie aktualność bardzo rzadko chodzi w parze z uniwersalnością. Ponadczasowość felietonów jest czymś cennym, sprawia, że felietony Stasiuka nawet za wiele lat od swego powstania będą atrakcyjne czytelniczo.

\section{Podsumowanie}

Stasiuk ocala to, co ukrywa się pod powierzchnią dominujących narracji, skoncentrowanych na aktualności. To, co nie jest aktualne, rozpatrywane jest w kategoriach: archaiczne, przebrzmiałe, passe, stare, niemodne. W rzeczywistości jednak drugą stronę medalu tworzy uniwersalność i ponadczasowość.

Stasiuk krytycznie podchodzi do naiwnego przekonania, iż to, co zapisane, przetrwa. Jest świadom tego, że w potoku słów, informacji, faktów, zdarzeń i sytuacji to, 
co istotne gubi się, wytraca. Autor smutno konstatuje, że słowa ulegają dewaluacji, przestają mieć swój ciężar i znaczenie.

Pęd za aktualnością jest niebezpieczny, ponieważ stępia zmysły, znieczula człowieka, oducza go myślącego, refleksyjnego spojrzenia. Teksty, w których widać ową chorobliwą fascynację aktualnością, bardzo szybko „tracą ważność” w znaczeniu podobnym jak produkty spożywcze: jełczeją pod wpływem czasu, psują się, stają się niezjadliwe, błahe, tragicznie nieaktualne. Kiedy człowiek reaguje niczym kobra na codzienność, jak metaforycznie pisze Stasiuk, to bardzo wiele umyka jego uwadze, właściwie umyka cały świat. Rzeczy ponadczasowe, relacje między zjawiskami pozostają niezbadane, rozpływając się w chwilowości, miałkości, błahości. Aktualność wyczerpuje uwagę, niweluje istnienie „było” i „będzie”, jest nastawiona wyłącznie na samą siebie, na teraźniejszość, która już za chwilę będzie przeżytkiem, przebrzmiałą pieśnią. Zbytnie skoncentrowanie na aktualnościach grozi fragmentaryzacją percepcji - poszczególne zdarzenia i sytuacje nie są porządkowane w ciągach logicznych, nie są powiązane ze sobą, ale istnieją oddzielnie, ponieważ umysł ludzki, zajęty pogonią za aktualnościami, nie jest w stanie poszczególnych elementów rzeczywistości łączyć w całości, scalać w jedno. Ludzie chcą żyć w pełni, żyć tu i teraz, i dlatego obierają błędną drogę pogodni za aktualnością, myśląc naiwnie, że dzięki temu teraźniejszość im nie ucieknie, że staną się jej panami, że będą w stanie głębiej i pełniej istnieć w świecie. Jest jednak inaczej - ślizgają się po powierzchni świata, zachłystują się coraz to nowymi zdarzeniami i faktami, tracąc z oczy szerszy kontekst.

Zapatrzenie w aktualność, w teraźniejszość oznacza zgubne w skutkach zamknięcie się przed przeszłością i przyszłością oraz wyklucza dostrzeganie palimpsestowej struktury świata. Śledzenie z uwagą teraźniejszości, reprezentowanej wyłącznie przez aktualność, stwarza pozory, że świat da się zrozumieć, stwarza złudzenie poczucia kontroli nad światem. Ślepej pogoni za aktualnością nie należy mylić, na co uwrażliwia lektura felietonów Stasiuka, z uważną kontemplacją chwili, z intensywnym byciem tu i teraz.

\section{Bibliografia}

BARAŃSKA-SZMITKO 2014: Barańska-Szmitko, A., Możliwości i ograniczenia felietonu jako narzędzia kreowania wizerunku jego autora // Acta Universitatis Lodziensis. Folia Litteraria Polonica. 2014/1(23): 211-227.

BERNACKI 2014: Bernacki M., Andrzeja Stasiuka przestrzenne doświadczenia Nicości: zapiski z wyprawy mongolskiej // Postscriptum Polonistyczne. 2014/1(13): 81-92.

ChudziŃSKI 2008: Chudziński, E., Felieton. Geneza i ewolucja gatunku // Dziennikarstwo i świat mediów, Bauer, Z., Chudziński, E. (ed.), Kraków: Universitas: 345-360.

COBEL-TOKARSKA-DĘBICKI 2018: Cobel-Tokarska, Magdalena - Dębicki, Marcin, Słowo i terytorium. Eseje o Europie Środkowej, Warszawa: Wydawnictwo Akademii Pedagogiki Specjalnej.

FRANKOWIAK 2011: Frankowiak A., „Wszystko zaczynało się od mojej obecności”. Sekretny przekaz prozy Andrzeja Stasiuka // Napis. 2011/XVII: 71-81. 
GOBAN-KLAS-SIENKIEWICZ 1999: Goban-Klas, Tomasz - Sienkiewicz, Piotr, Społeczeństwo informacyjne: szanse, zagrożenia, wyzwania, Kraków: Wydawnictwo Fundacji Postępu Komunikacji.

HERER 2012: Herer, Michał, Filozofia aktualności, Warszawa: Wydawnictwo Naukowe PWN. NICZYPEROWICZ 1996: Niczyperowicz, A. Przepis na felieton // Abecadło dziennikarza.Niczyperowicz, A (ed.), Poznań: Kontekst: 45-57.

NoRwID 1968: Norwid, C. K. O felietonie felieton // Norwid, C. K., Pisma zebrane. Proza, t. 4, Warszawa: Państwowy Instytut Wydawniczy: 185.

SANDAUER 1971: Sandauer, Artur, Liryka i logika. Wybór pism krytycznych, Warszawa: Państwowy Instytut Wydawniczy.

SETLAK 2015: Setlak W., Twórca wobec przestrzeni i czasu. Przyczynek do rozważań o filozofii mobilności Andrzeja Stasiuka // Tematy i konteksty 2015/5(10): 31-45.

STASIŃSKI 1982: Stasiński, Piotr, Poetyka i pragmatyka felietonu, Warszawa: Zakład Narodowy im. Ossolińskich.

STASIUK 2018: Stasiuk, Andrzej, Kroniki beskidzkie i światowe, Wołowiec: Czarne.

WiTOsz 2002: Witosz B., Obrona bliskości w prozie Andrzeja Stasiuka // Teksty Drugie 2002/5: 129-140.

WOLNY-ZMORZYŃSKI et al. 2006: Wolny-Zmorzyński, Kazimierz - Kaliszewski, Andrzej Furman, Wojciech, Gatunki dziennikarskie. Teoria, praktyka, język, Warszawa: Wydawnictwa Akademickie i Profesjonalne.

\author{
Agnieszka JANIEC-NYITRAI \\ Eötvös Loránd University \\ Budapest, Hungary \\ janiec.nyitrai@gmail.com
}

